\title{
Solid Waste Management and Design of a Sanitary Landfill for Sohar Area
}

\author{
${ }^{1}$ Osama Ragab, Assem Ali Al Al Darwasha \\ ${ }^{1}$ Assistant Professor (Author), \\ Civil Engineering Department \\ Faculty of engineering, Sohar University \\ Sohar, Sultanate of Oman
}

\begin{abstract}
Uncontrolled waste disposals are considered as a huge risk to environment human's and animal's health. Moreover, with the constant increasing in population; a source of energy is required for several demands; such as the electricity and cooking demands. Sanitary landfills are considered as the dominant option for municipal solid waste disposal due to its sophisticated containment systems, environmental monitoring, improved operational practices and increased regulation. The research has numerous targets; forming a potential methane emission table in Sohar for cattle's dang, and a mix of Human's waste with cattle's dang based on Sohar climate. Usage of an Engineered Bioreactor Landfill to simulate a Sanitary Landfill of a three years' lifetime that's suitable for Sohar area based on the population and Waste per Capita. Usage of a Bioreactor Landfill to cover the farm or housing unit's demands regarding the required energy for cooking or electricity. Applying an innovative method to simulate a Sanitary Landfill in 100 gallons' tanks, using the Flux Chamber method and the First Order Decay (FOD) model. Finally, analyzing of the effective parameters regarding the emission calculations using a hand-made device and comparing the results with high-tech and worth devices.
\end{abstract}

Keywords:- Solid Waste; Sanitary; Sohar; Management

\section{INTRODUCTION}

In the prevailing scenario, uncontrolled waste - waste is in a direct relationship with the population - disposals are considered as a huge risk to environment human's and animal's health, thus, the waste's management is essential. Moreover, with the constant increasing in population; a source of energy is required for several demands; such as the electricity and cooking. The main objectives of this research as follows: Forming a potential table for Methane Emissions in Sohar area, designing of a 3-year life time Sanitary Landfill that's suitable for Sohar area and Designing of a Hand-made device to analyze the Landfill parameters and compare them with High-tech devices.

\section{LITREATURE REVIEW AND THEORY}

\section{A. Sanitary Landfills}

Based on the use approach, sanitary landfills are considered as modern landfills. Due to limited access of water in sanitary landfills, moisture content levels of the waste are low, which results in slight volumes of leachate and LFG $^{(21)}$

The system includes two main layers ${ }^{[10]}$ aligned layer by layer; the final cover system which is the top visual layer of the landfill, with functions of; controlling moisture content, percolation, supporting surface water runoff, preventing erosion and minimizing the odors ${ }^{[34]}$, and the landfill liner system is the system that has four types as single, composite, double and multiple liner system. The last type is a mix of liner materials and leachate collection layers placed below the waste cells, with purposes of collecting and containing the leachate and LFG. ${ }^{[29]}$

The Final Cover system shown in figure 1 has different cross sections. Cross-section B consists of a cover vegetation layer ${ }^{[34]}$ as shown in figure 2, a final Cover layer which consists of a drainage layer, a separation and protection layers that consist of a doubled layer of geotextile with a geomembrane layer installed between them [29],[25],[3] and a Top soil layer [34], [10], [3]. The working landfill system which consist of a daily Cover and intermediate cover layers [29], [10] and the Waste Cells ${ }^{[29]}{ }^{[10]}$. The cross-section A consists of a leachate collection system. Cross-section $\mathrm{C}$ has the landfill leachate collected that transported to the holding tanks to dispose it through leachate recycling or evaporation, or discharged to the leachate management facilities for treatment [15], [29], [3]. A separation and protection layer with similar specifications as the one on the final cover system ${ }^{[29]}$, and a groundwater collection system ${ }^{[29]}$ are shown in figure 3,4 . The liners are generally placed at a minimum of $2 \%$ slope and pipes are laid at $1 \%$ slope to ease the leachate flow through the collection system which prevents gathering of leachate in the low lying areas of the landfill ${ }^{[15]}$ as shown in figure 5. Complex liner systems (composite liner system, double liner system and multiple liner system) are used prevent leachate leakage and fully contamination of leachate [29].

\section{B. Bioreactor Landfills}

According to the Environmental Protection Agency (EPA), a bioreactor landfill is an ordinary landfill with enlarged microbial processes which leads to an increase in waste decomposition and stabilization which leads to a shorter life span than the convention landfill ${ }^{[37]}$. The increase in the microbial processes occurs due to the controlled addition of 
leachate [21], [26], [37]. The Bioreactor Landfill has three types; the Anaerobic Bioreactor Landfill which seeks to optimize the proper conditions for the anaerobic bacteria in order to accelerate the degradation process of waste [21], [30], Aerobic Bioreactor Landfill and Hybrid Bioreactor Landfill [21], [30].

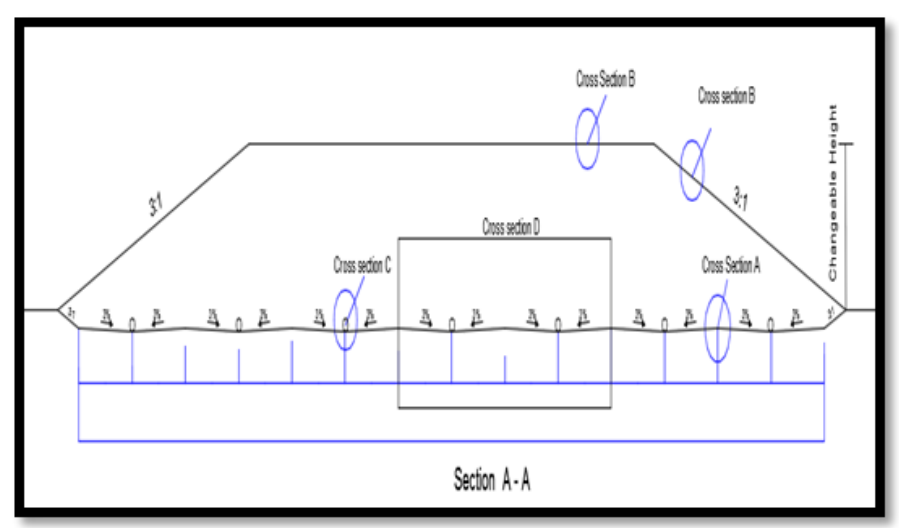

Fig.1: Detailed Landfill drawing (D.L.d)

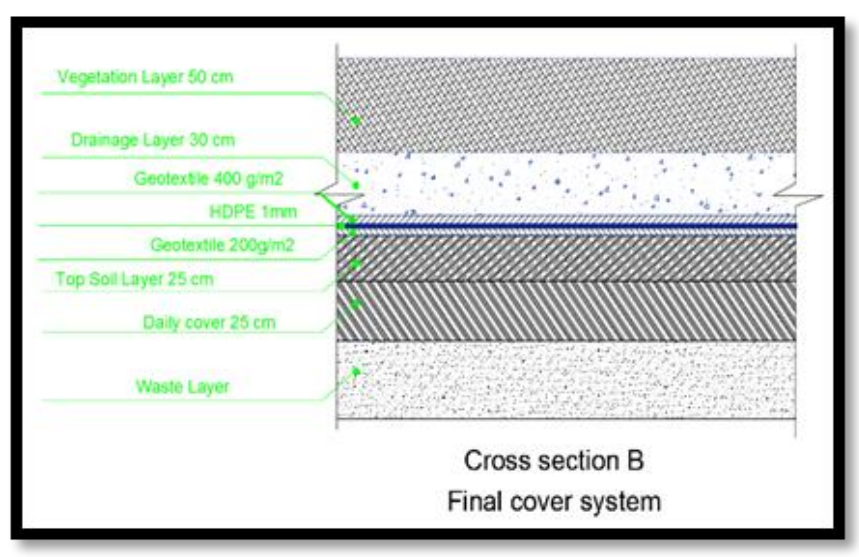

Fig.2: D.L.d Cross-section B.

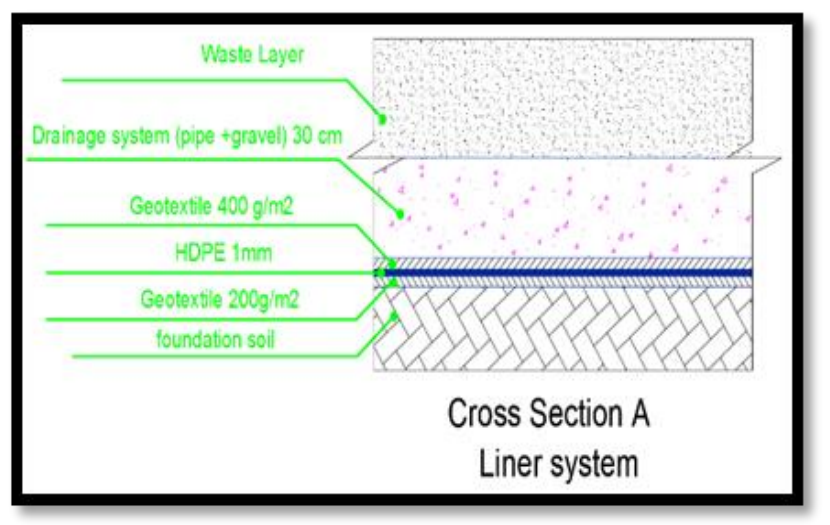

Fig.3: D.L.d Cross-section A.

\section{c. Bioreactor Lanfdfill Gas Collection System Types}

Active collection systems which relies on mechanical blowers or compressors to provide the required pressure to extract the LFG flow from the gas collection header with high efficiency to combust it or to use it as a source of energy [35], and the Passive Collection Systems which relies on the Landfill's internal pressure to extract the LFG to store it or releasing it to the atmosphere ${ }^{[35],[32]}$.

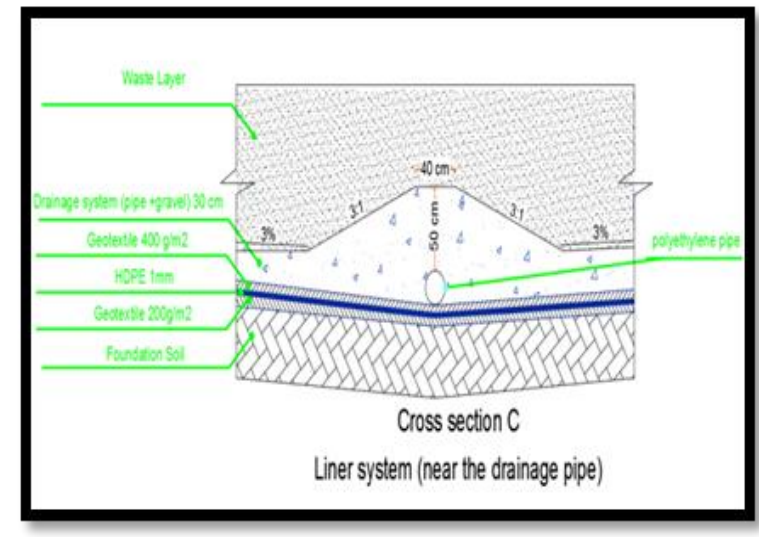

Fig.4: D.L.d Cross-section C.

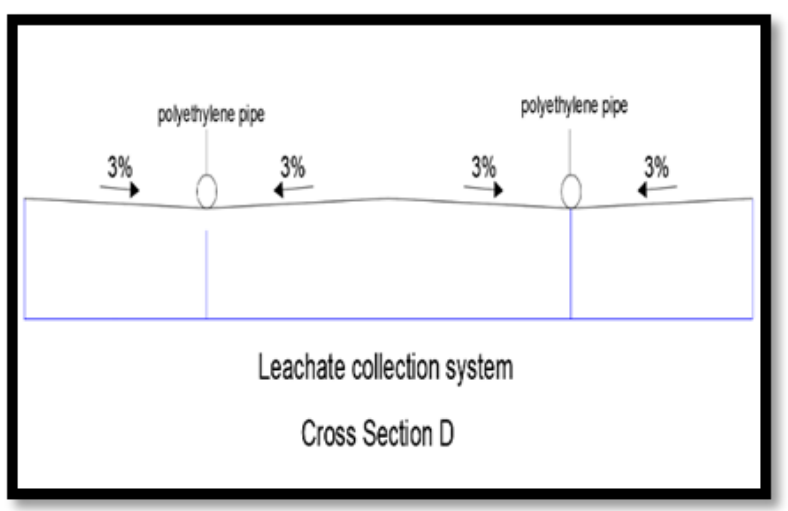

Fig.5: D.L.d Cross-section D.

Among the most common types of LFG Collection system used for both the Active Collection System and the Passive Collection Systems are the Vertical Well - basically is a pipe with a solid pipe part extending through the Final Cover system to the top visual side of the Landfill then linked to the Gas Collection Header, and a perforated pipe part surrounded by a Butanone perforated pipe and Gravel installed inside the landfill's compacted waste layer ${ }^{[35],[3],[19]}$ and Trench Systems - installed within a landfill cell as each layer of waste is applied [35], [28] -. The Vertical Well or Trench Systems are linked to the Gas Collection Header, which transfers the LFG flow to the Flaring/Cogeneration Station. The Gas Collection Header is designed in order to maximize the LFG generation rates and minimizing the pressure drop, however, the Gas Collection Header size relies on the total LFG flow rate and pressure drop ${ }^{[35]}$. In case of using an Active Collection system, a Blower or Compressor links the Flaring/Cogeneration Station with the Gas Collection Header [35]. Generally, the placement and spacing between gas extraction wells depends on the type of waste and it's compaction degree, depth of the well, LFG generation rates, Landfill's depth, moisture content of LFG and the magnitude of the applied pressure by the blower or the compressor [35], ${ }^{[19]}$. However, the spacing between the gas extraction wells is about 15 to $90 \mathrm{~m}$ approximately ${ }^{[35]}$. 


\section{d. LFG to Energy Considerations}

The LFG collected is considered as an energy source and can be used to; generate electricity, as an alternative fuel supply, as an alternative for Fossil fuels, Heating, etc....

The usage of LFG as an energy source reduces risks related to Methane migration to the atmosphere and reduces odors ${ }^{[35]}$, [32]. Sanitary Landfill Settlement theory is clarified in [21], [37], [29]

\section{METHODOLOGY}

This part illustrates the method applied to get the LFG concentrations, temperature, humidity and leachate PH. it also explains the method to design and manage a Sanitary Landfill. The LFG emission values are found according to the IPCC 2006 emission equation guidelines, the emission values are used to form the Methane emissions potential table and designing of the Sanitary Landfill. The chapter also illustrates the calibration basis of the Hand-made device.

The used tanks are two 100 gallon PVC Tanks as shown in figure 6 with a 0.5 in hole diameter on top linked to a Tsection which is used to collect the LFG (Landfill Gas). LFG quantities are controlled using valves with 1.5 in hole diameter on bottom with a valve to control the Leachate amounts that used as a Leachate outlet which is used for the purpose of recirculation. A slope is provided to ease the extraction of Leachate by placing the tanks over Gravel and a 0.5 in hole diameter on the side to insert the electronic equipment inside the tank in order to measure the gases concentrations $\mathrm{CH} 4$ and $\mathrm{CO} 2$, temperature and humidity. A Foam is used to cover the hole entirely to prevent any leakages of LFG. The tanks consist of three Layers aligned layer by layer from bottom to top. A $15 \mathrm{~cm}$ in depth Layer of Aggregate is placed and a waste layer with two types of waste has been used like Cattle`s dung and vegetable waste. In addition, a $20 \mathrm{~cm}$ in depth layer of compacted soil. The bioreactor which is used to simulate the gas collection system contains waste layer with uncompact $30 \mathrm{~cm}$ depth. It also consists of a mixture of a $100 \%$ cattle dung and water as shown in table.1 with a (1:1) ratio. The compacted waste layer $25 \mathrm{~cm}$ depth is the Second bioreactor (Engineered Bioreactor Landfill) which is used to simulate the Sanitary Landfill with waste layer. This layer is uncompacting $35 \mathrm{~cm}$ depth that consists of a mixture of water and a combination of 70\% human waste and 30\% cattle dung as shown in table. 2 with a (1:0.5) ratio. The compacted waste layer depth is 25 $\mathrm{cm}$ before placing the waste layer inside the bioreactors, the waste mixed is poured and mixed inside aluminum tanks.

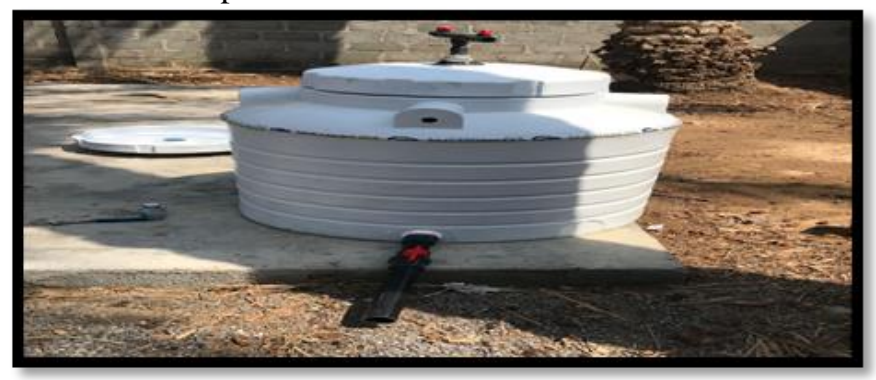

Fig.6: PVC Tank
TABLE 1: WEIGHT OF EACH MIX

\begin{tabular}{|l|l|}
\hline Mix No. & \multicolumn{1}{|c|}{ Weight (Cattle Dung and Grass) Kg } \\
\hline 1 & $64(32$ Waste +32 Water $)$ \\
\hline 2 & $46(23$ Waste +23 Water $)$ \\
\hline 3 & $74(37$ Waste +37 Water $)$ \\
\hline 4 & $50(25$ Waste +25 Water $)$ \\
\hline 5 & $16(8$ Grass +8 Water $)$ \\
\hline \multicolumn{2}{|l}{} \\
\end{tabular}

The data analyses parameters are LFG concentrations, Temperature, Humidity and Leachate PH that are taken each two weeks for each tank for a period of 20 min with a 5 min interval between each reading - October, November and December are the study period months -. The data analyses parameters are taken using the Gas Chromatography (GC) device which is used to get the LFG Concentrations, the Extech device (Humidity alert 2) which is used to get the Temperature and Humidity - according to (Extech Instruments) the device has a $\pm 4 \%$ RelativeHumidity and $\pm 1^{\circ} \mathrm{C}$ Temperature accuracy -, the WTW PH meter 720 which is used to get the Leachate $\mathrm{PH}$ - the device has a $\mathrm{PH}$ range of -2.00 to +16.00 accuracy -, and the Handmade device - Handmade Gas Analysis system as shown in figure 7 - which is used to get the Temperature, Humidity and LFG Concentrations. The Hand-made device consists of an Arduino Uno, a Graphic LCD $84 \times 48$ - Nokia 5110 which is used to display the readings, a Humidity and Temperature Sensor device, an Mq6 sensor device which is used to detect the concentration of $\mathrm{Co} 2$, and an $\mathrm{Mq} 4$ sensor device which is used to detect the concentration of $\mathrm{CH} 4$. The Hand-made device calibrating method used is a basic method (Trial and Error) method.

To measure the data analyses parameters; a fan is fixed inside the tank - as the Bioreactor layer`s filled - to attain sufficient mixing of the gases, the Tank cover is placed and the T-section valves are closed properly, a PVC tube is properly fixed on one of the T-section sides, the other part of the tube is connected to a Vacuum Motor to draw out the LFG, the other part of the Vacuum Motor - provided with a PVC tube - pumps the LFG to a Gas Sampling Bag Tedlar ${ }^{\circledR}$ Gas Sampling Bags are recommended in many US EPA methods due to its high leak-proof, impermeability and abrasion resistance -. Before taking the Readings, the Sampling Bags are filled with oxygen using the Vacuum Motor - which is connected to a Battery - through a PVC tube and drowned out of it for the purpose of cleaning (The procedure is applied 3 times). The T-section valve connected to the Vacuum Motor is opened and a timer is set for each 5 minutes for 8 times ( 4 times for each tank) to pump the LFG from the Tank to the Sample Bag. After filling the Sampling Bags for each Tank, the Leachate valve is opened for the purposes of recirculation and taking samples for analyses. The Sampling Bags are analyzed using the (GC) device to get the LFG concentrations. 
TABLE 2: WEIGHT OF MIXES

\begin{tabular}{|l|l|}
\hline $\begin{array}{l}\text { Mix } \\
\text { No. }\end{array}$ & \multicolumn{1}{|c|}{ Weight (Cattle Dung, Vegetable Waste and Grass) Kg } \\
\hline 1 & $\begin{array}{l}\text { 89 (12.7 Cattle Waste + 12.7 Water + 42.4 Vegetable Waste + } 21.2 \\
\text { Vegetable Water) }\end{array}$ \\
\hline 2 & $\begin{array}{l}93.1 \text { (13.3 Cattle Waste + 13.3 Water + 44.3 Vegetable Waste + } \\
\text { 22.2 Vegetable Water) }\end{array}$ \\
\hline 3 & $\begin{array}{l}\text { 68.4 (9.8 Cattle Waste + 9.8 Water + 32.5 Vegetable Waste + 16.3 } \\
\text { Vegetable Water) }\end{array}$ \\
\hline & $\begin{array}{l}\Sigma=250.5 \mathrm{Kg} \text { [Distributed as } 35.8 \mathrm{Kg} \text { Cattle dung }(1: 1) \\
\text { and } 119.2 \mathrm{Kg} \text { Vegetable Waste }(1: 0.5)\end{array}$ \\
\hline
\end{tabular}

Fig.7: Handmade Gas Analysis System

\section{a. Landfill Design}

IV. RESULTS AND DISCUSSION

The population waste/3 years which is found by multiplying the population by waste per capita ( $\mathrm{kg} / \mathrm{capita} / \mathrm{day})$ is used to get the compacted Volume of Waste which equals the addition of the upper and lower Trapezoids of the Landfill.

The Depth of the first Trapezoidal $\left(V_{1}\right)$ is $3 \mathrm{~m}$, while the Depth of the second Trapezoidal $\left(V_{2}\right)$ is $20 \mathrm{~m}$. The upper and lower Width of the first Trapezoidal $\left(V_{1}\right)$ are $118 \mathrm{~m}$ and $100 \mathrm{~m}$, while the upper and lower Width of the second Trapezoidal $\left(V_{2}\right)$ are $118 \mathrm{~m}$ and $38 \mathrm{~m}$. The third dimension of the landfill is found by applying the previous values in the Compacted Volume of Waste equation, which is found to be $65 \mathrm{~m}$. The Landfill constructed in Oman location is shown in (Fig.8). The Landfill is located at a distance of $16 \mathrm{~km}$ far from Sohar. The precipitation data through 19 years is collected - starting from 2000 -, the highest precipitation values were in December 2017. The total precipitation is found to be $22.1983 \mathrm{~mm}$. To get the quantity of Drainage Polyethylene Pipes on the $3 \mathrm{yr}$ Sanitary Landfill base; the flow $(\mathrm{Q})$ is found by dividing the (total of Rain and Waste Volume) by the Average Storm time in Oman - which is assumed as 3 hours -, the Volume of Rain is found by multiplying the total precipitation by the Surface area of the Landfill, the $\mathrm{Q}$ is found to be $0.3554 \mathrm{~m}^{3} / \mathrm{sec}$. The Perforated or Solid part of the pipe area is found by dividing the $Q$ over the $1 \mathrm{~m} / \mathrm{sec}$ velocity, then assume the Half-pipe diameter as $30 \mathrm{~cm}$, next the number of pipes $(\mathrm{N})$ is applied on the area equation. The $\mathrm{N}$ required equals to 11 pipes. Finally, the distance between the Drainage Polyethylene
Pipes is found by dividing the $100 \mathrm{~m}$ base over $\mathrm{N}$, which results in $9 \mathrm{~m}$ distance. The Perforated or Solid part of the pipe area and $\mathrm{N}$ are used to get the diameter of the Header pipe. The Holding Tanks will receive the (total of Rain and Waste Volume), it`s Length is assumed as $50 \mathrm{~m}$ and Depth as $2 \mathrm{~m}$, then the Width is found - which equals to $32 \mathrm{~m}$.

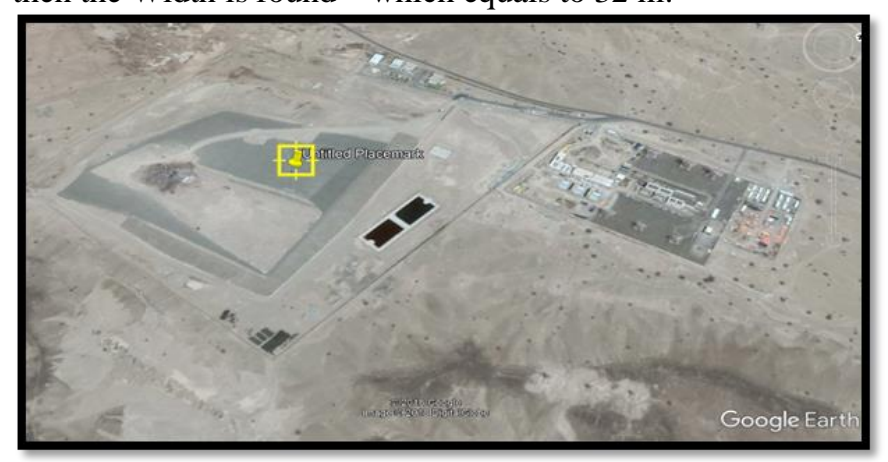

B. Data Analysis

Fig.8: Oman Landfill Location

The First Reading was taken at 9 am on 10/October/2018, the Second Reading was taken at 12:30 pm on $24 /$ October/2018, the Third Reading was taken at 12:30 pm on $7 /$ November/2018, the Fourth Reading was taken at $1: 30 \mathrm{pm}$ on $25 /$ November/2018, and the Fifth Reading was taken at 12:30 pm on 9/December/2018. The inner Temperature is measured in Celsius from the Extech and the Hand-made (AU) devices, the Humidity in percentage from the Extech and the Hand-made (AU) devices, the LFG ( $\mathrm{CH} 4$ and $\mathrm{CO} 2)$ concentrations are measured from the (GC) device - $\mathrm{CH} 4$ in ppm and $\mathrm{CO} 2$ in percentage. After the concentration values are found, the slope curve of concentration rate is found $\left(\frac{\mathrm{dc}}{\mathrm{dt}}\right)$, a sample of do the $(\overline{\mathrm{dt}})$ curves for the First reading are clarified in figures 9,10 .

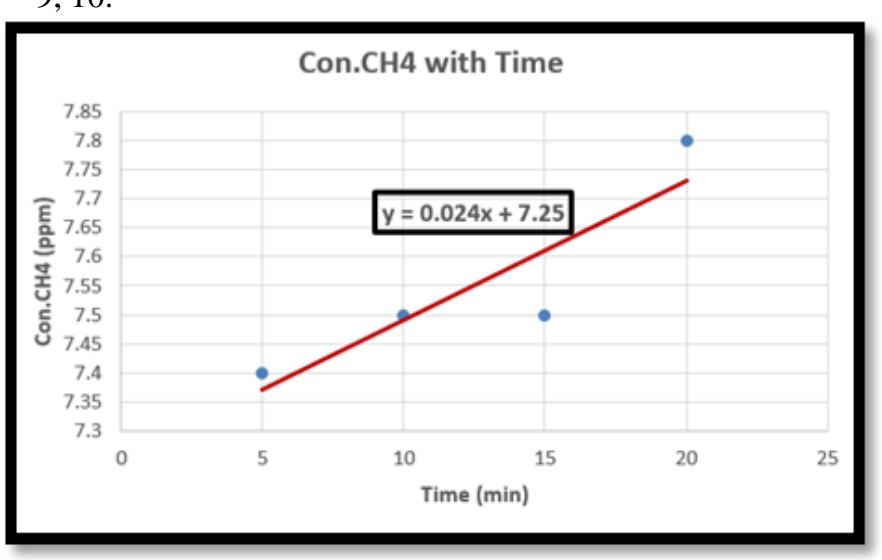

Fig.9: First Reading $\frac{d c}{d t}$ value for First Bioreactor C. 


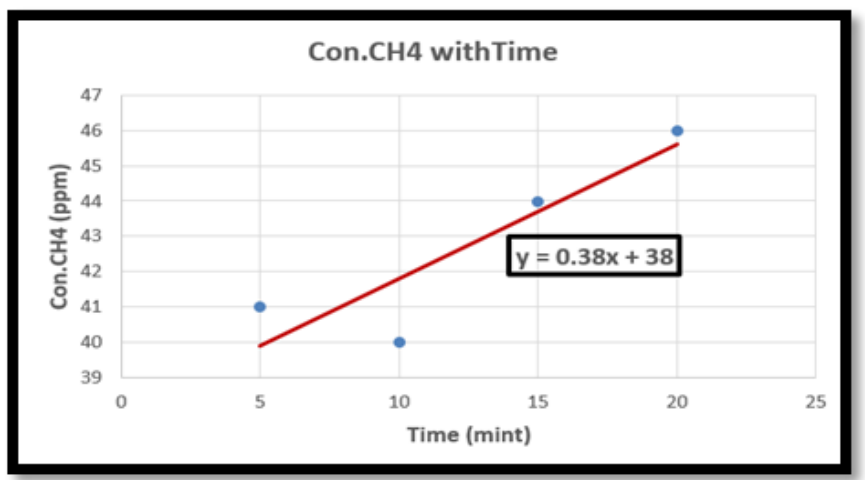

Fig.10: First Reading $\frac{\mathrm{dc}}{\mathrm{dt}}$ value for First Bioreactor V.

\section{Model Methane Emission Results}

Various methods of measuring methane gas emission from landfills were inspected and developed - through the years -by several researchers across the globe [22]; The Default Method [22], The First Order Decay (FOD) method which is an IPCC method developed from the Default Method [2], The LandGEM method [11]. The (FOD) model is applied to get the Methane emission values. The Methane emission values of Bioreactor $\mathrm{C}$ are shown in (Table.3), while the Methane emission values of Bioreactor $\mathrm{V}$ are shown in (Table.4).

TABLE 3: Bioreactor (C) Methane Emission values

\begin{tabular}{|c|c|c|c|c|c|c|c|c|c|}
\hline Week. & $\begin{array}{l}\mathrm{P} \\
\mathrm{atm}\end{array}$ & $\mathrm{V} \mathrm{m}^{3}$ & $\mathrm{M} \frac{\mathrm{g}}{\mathrm{mol}}$ & $\mathrm{U} \mathrm{L}_{\mathrm{a}} \min / \mathrm{L}_{\mathrm{x}}$ day & $\mathrm{A} \mathrm{m}^{2}$ & $\mathrm{R}\left(\mathrm{L}_{\mathrm{r}} \mathrm{atm} /{ }^{\circ} \mathrm{K} \cdot \mathrm{mol}\right)$ & $\mathrm{T}^{\square} \mathrm{K}$ & $\frac{d s}{d t}$ & $\mathrm{~F}\left(\mathrm{~g} / \mathrm{m}^{2}\right.$. day $)$ \\
\hline 1 & 1 & 0.209 & 16 & 0.00144 & 0.58 & 0.08205 & 315.05 & 0.024 & 0.00168 \\
\hline 2 & 1 & 0.209 & 16 & 0.00144 & 0.58 & 0.08205 & 306.35 & 0.042 & 0.00296 \\
\hline 3 & 1 & 0.209 & 16 & 0.00144 & 0.58 & 0.08205 & 308.2 & 0.058 & 0.00406 \\
\hline 4 & 1 & 0.209 & 16 & 0.00144 & 0.58 & 0.08205 & 306.85 & 0.1 & 0.00703 \\
\hline 5 & 1 & 0.209 & 16 & 0.00144 & 0.58 & 0.08205 & 306 & 0.2 & 0.01443 \\
\hline
\end{tabular}

The PH values in both tanks are adequate (6-9 range), since $\mathrm{V}$ is $7.086 \%$. The humidity in Bioreactor $\mathrm{V}$ is relatively higher substance is used to control PH value. The average rate of ince nquan the humidity in Bioreactor $\mathrm{C}$ due to the wetter environment in substance is used to control PH value. The average rate of increasênioreactor $\mathrm{V}$, which is provided by the vegetable waste. The handin Bioreactor $\mathrm{C}$ is $\mathbf{5 . 8 6 2 \%} \%$, while in Bioreactor $\mathrm{V}$ is $3.2 \%$.

Regarding the relation between Temperature and Time for me device Humidity values are accurate with a $95 \%$. Bioreactor $\mathrm{C}$ and Bioreactor V; although that the average rate o decrease in Bioreactor $\mathrm{C}$ and Bioreactor $\mathrm{V}$ is similar $\left({ }^{0.72 \%}\right)$, th(Fig.12). Although that the average rate of increase in Bioreactor $\mathrm{C}$ temperature in Bioreactor $\mathrm{V}$ is relatively lower than the temperature $73 \%$ ) is much higher than in Bioreactor $\mathrm{V}(28.105 \%)$, the

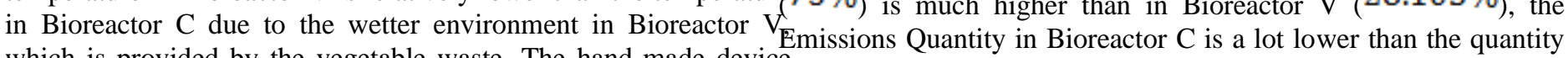
which is provided by the vegetable waste. The hand-made device in Bioreactor V.

Temperature values are accurate with a $95 \%$. About the relation between Humidity and Time for Bioreactor $\mathrm{C}$ and Bioreactor V; the average rate of increase in Bioreactor $\mathrm{C}$ is $3 \%$, while in Bioreactor

TABLE 4: Bioreactor (V) Methane Emission values

\begin{tabular}{|c|c|c|c|c|c|c|c|c|c|}
\hline Week & Patm & $\mathrm{Vm}^{2}$ & $\mathrm{M} \frac{\mathrm{g}}{\mathrm{ms} !}$ & $\mathrm{U} \mathrm{L}_{\min } / \mathrm{L}$ day & $\mathrm{Am}^{2}$ & $\mathrm{R}$ (L-atm/2K,mol) & $\mathrm{T} \mathrm{D}^{\mathrm{K}}$ & 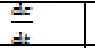 & $\mathrm{F}\left(\mathrm{g} / \mathrm{m}^{2}\right.$.day $)$ \\
\hline 1 & 1 & 0.209 & 16 & 0.00144 & 0.58 & 0.08205 & 310.65 & 0.38 & 0.02669 \\
\hline 2 & 1 & 0.209 & 16 & 0.00144 & 0.58 & 0.08205 & 306.5 & 0.34 & 0.0236 \\
\hline 3 & 1 & 0.209 & 16 & 0.00144 & 0.58 & 0.08205 & 301.85 & 0.6 & 0.04148 \\
\hline 4 & 1 & 0.209 & 16 & 0.00144 & 0.58 & 0.08205 & 302.975 & 0.7 & 0.04983 \\
\hline 5 & 1 & 0.209 & 16 & 0.00144 & 0.58 & 0.08205 & 301.75 & 0.0344 & 0.00237 \\
\hline
\end{tabular}

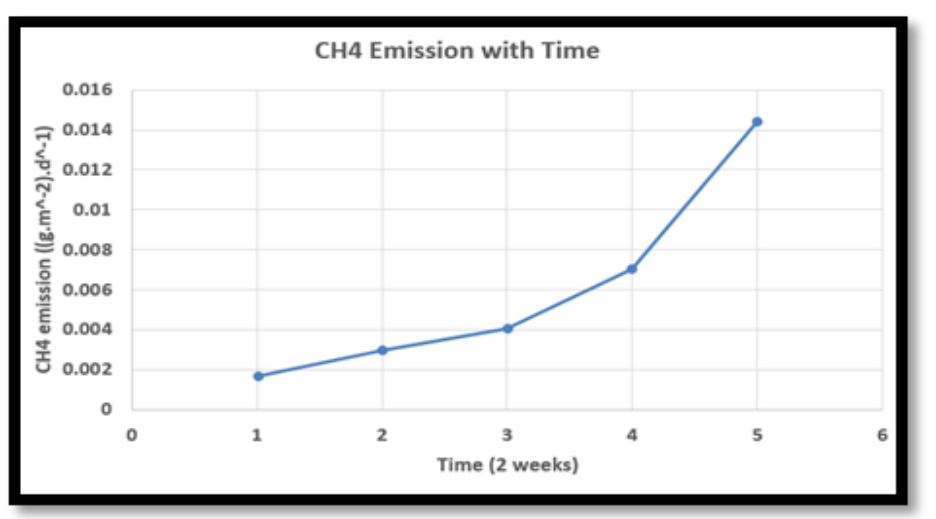

Fig.11: Bioreactor C (CH4 Emission. Time curve).

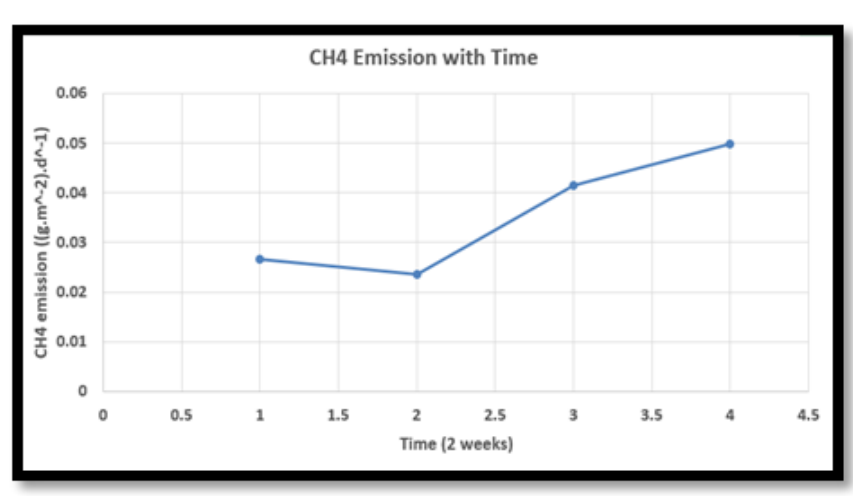

Fig.12: Bioreactor V (CH4 Emission. Time curve). 
The relation between Methane Emission values and Temperature with respect to Time for Bioreactor $\mathrm{C}$ and Bioreactor $\mathrm{V}$ are illustrated in (Fig.13) and (Fig.14). The relation between Methane Emission values and Humidity with respect to Time for Bioreactor $\mathrm{C}$ and Bioreactor $\mathrm{V}$ are illustrated in (Fig.15) and (Fig.16).

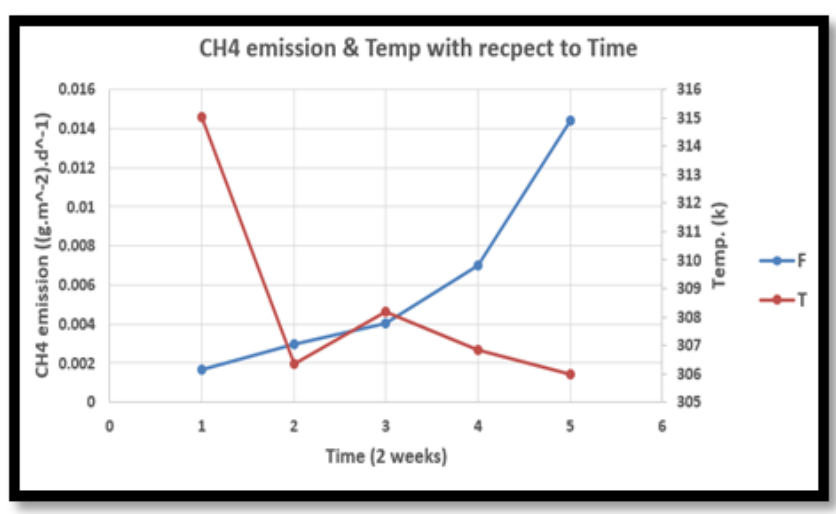

Fig.13: Bioreactor C.

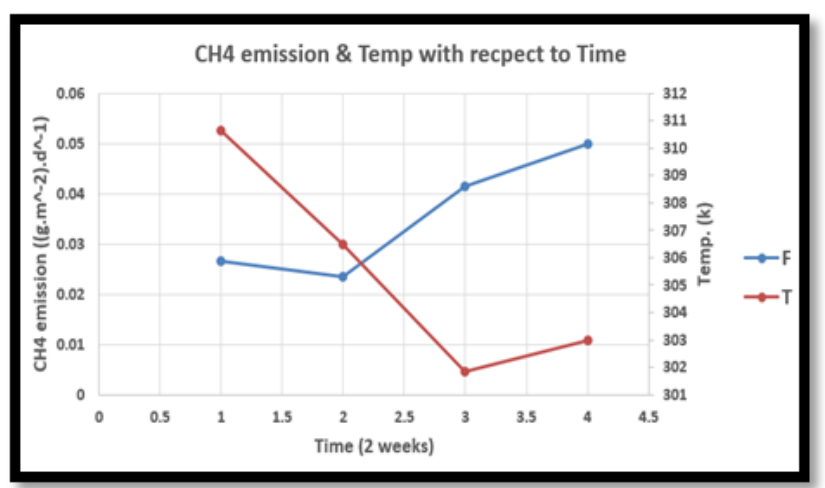

Fig.14: Bioreactor V.

The relation between Methane Emission values and $\mathrm{PH}$ with respect to Time for Bioreactor $\mathrm{C}$ and Bioreactor $\mathrm{V}$ are illustrated in (Fig.17) and (Fig.18). The relation between Methane Emission values and Methane average concentration for Bioreactor C and Bioreactor V are illustrated in (Fig.19) and (Fig.20). The average rate of increase of Methane Concentration in Bioreactor $\mathrm{C}$ is $4.18 \%$, while in Bioreactor $\mathrm{V}$ is $5.2 \%$. The average rate of increase of Emission in Bioreactor $\mathrm{C}$ is $72.94 \%$, while in Bioreactor $\mathrm{V}$ is $28.1 \%$. The concentrations measured by the hand-made device compared with the GC are accurate with $45 \%$, which is low value. The error is in the calibration, as the calibration with adequate accuracy requires a calibration specialist.

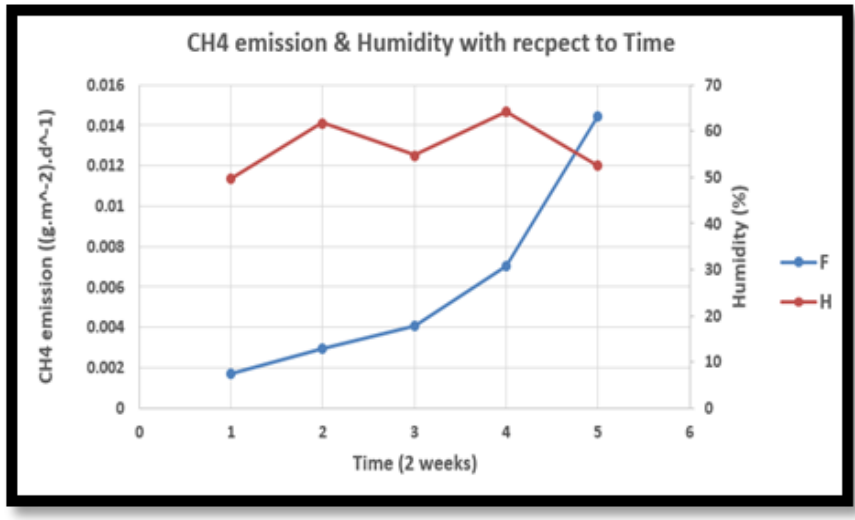

Fig.15: Bioreactor C.

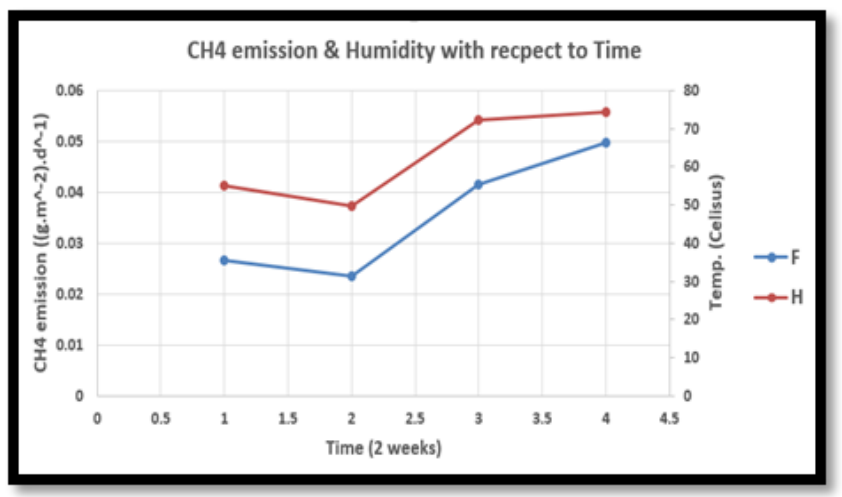

Fig.16: Bioreactor V.

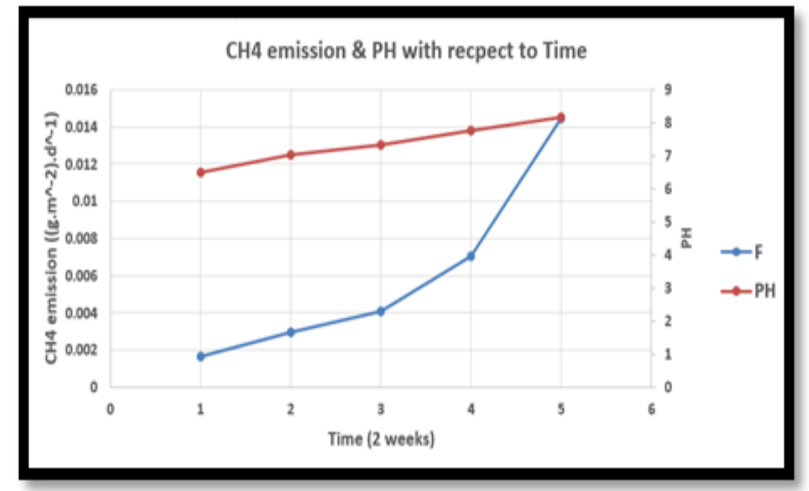

Fig.17: Bioreactor C.

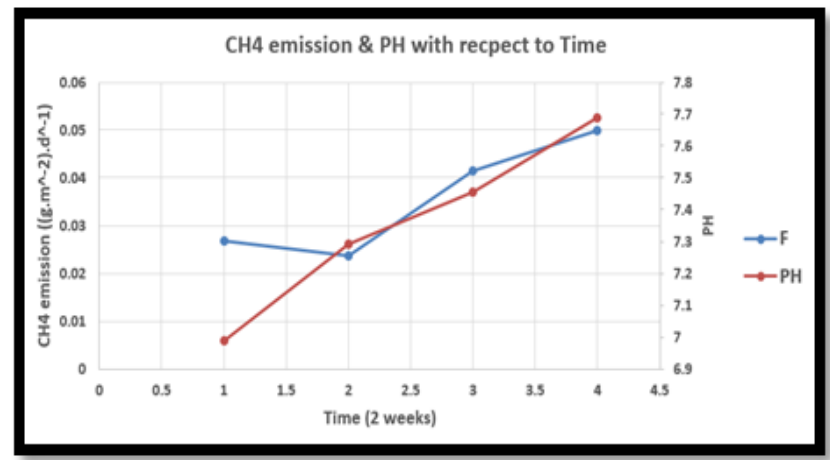

Fig.18: Bioreactor V. 


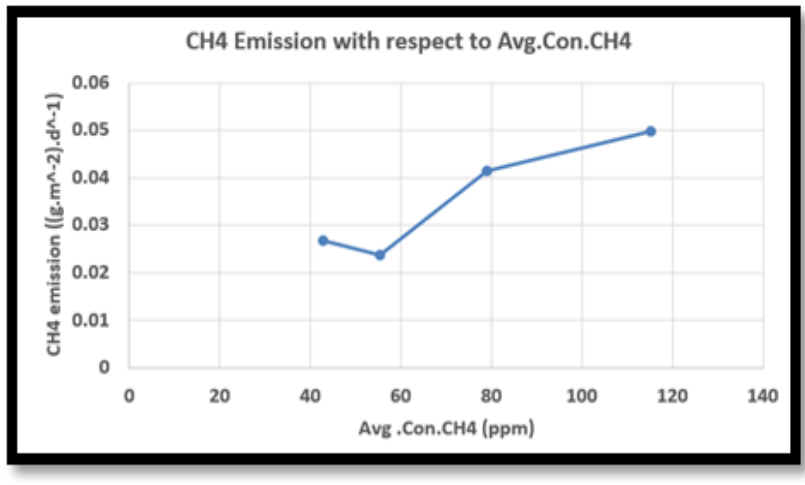

Fig.19: Bioreactor C.

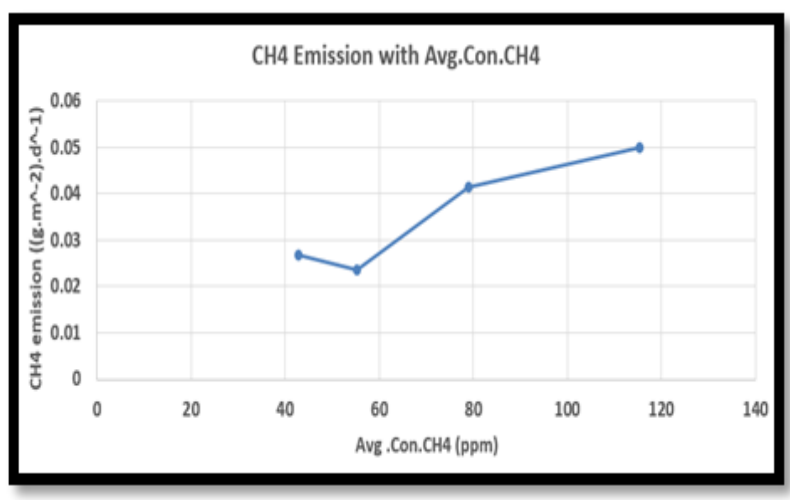

Fig.20: Bioreactor V

The Methane Emission Potential table values of Bioreactor $\mathrm{C}$ are shown in (Table.5). The Methane Emission Potential table values of Bioreactor $\mathrm{V}$ are shown in (Table.6). The Methane Emission Potential table values of Bioreactor V are used to design the Three year Sanitary Landfill, Bioreactor $\mathrm{V}$ average amount of Emission values for the three studied months for $1 \mathrm{TON}=0.1416\left(\mathrm{~g} / \mathrm{m}^{2}\right.$.day $)$.

Table.5: Bioreactor (C) Methane Emission Potential table

\begin{tabular}{|c|c|c|}
\hline Week. & \multicolumn{1}{|c|}{$\mathrm{F}(250 \mathrm{Kg})$} & $\mathrm{F}(1 \mathrm{Ton})$ \\
\hline 1 & 0.00168 & 0.00672 \\
\hline 2 & 0.00296 & 0.01184 \\
\hline 3 & 0.00406 & 0.01624 \\
\hline 4 & 0.00703 & 0.02812 \\
\hline 5 & 0.01443 & 0.05772 \\
\hline
\end{tabular}

Table.6: Bioreactor (V) Methane Emission Potential table values

\begin{tabular}{|l|l|c|c|}
\hline Week. & $\mathrm{F}(250 \mathrm{Kg})$ & $\mathrm{F}(1 \mathrm{Ton})$ & $\mathrm{F}(3 \mathrm{Yr})$ \\
\hline 1 & 0.02669 & 0.10676 & 8160.42529 \\
\hline 2 & 0.0236 & 0.0944 & 7215.662677 \\
\hline 3 & 0.04148 & 0.16592 & 12682.4444 \\
\hline 4 & 0.04983 & 0.19932 & 15235.44369 \\
\hline 5 & 0.00237 & 0.00948 & 724.6237518 \\
\hline
\end{tabular}

\section{CONCLUSION}

The variety between the values of Methane Emissions Potential table between the two Bioreactors, -Through the study month`s-Tank V has higher Emission quantity (0.01-
0.2) than Tank C (0.01-0.1) (Although Tank C Average rate of increase is higher than Tank V).

The average predicted amount of Methane Emission for one ton the for Sanitary Landfill to be designed around $0.1416\left(\mathrm{~g} / \mathrm{m}^{2}\right.$.day $)$.

The relationship between Methane Emission with Temperature and Humidity with respect to time, As the temperature decrease the Humidity increase and the Emission increases in both Tanks

The Calibration error regarding the Concentration between the Hand-made device and the GC is high (around 55\%), as it needs an expert opinion in calibration.

The Calibration error regarding the Temperature and Humidity between the Hand-made device and the Extech device is lower than $5 \%$.

\section{ACKNOWLEDGMENT}

Particular gratitude for the individuals in Orbic Company and municipality of sewage control who supported us throughout the study period. Also, special thanks to our family members and friends for all the support and encouragement to do our maximum effort for this research.

\section{REFERENCES}

[1] Abushammala, M. F., Basri, N. E., \& Younes, M. K. (2016). Seasona Variation of Landfill Methane and Carbon Dioxide Emissions in a Tropical Climate. International Journal of Environmental Science and Development, Vol. 7, No. 8, 1-5.

[2] Abushammalaa, M. F., Basria, N. E., Basria, H., Kadhumb, A. A., \& El-Shafiea, A. H. (2012). Methane and carbon dioxide emissions from Sungai Sedu open dumping during wet season in Malaysia. Ecological Engineering, 254-263.

[3] Al Drawsha Environmental Consultant Office. Drawings about the Landfill Layers

[4] Allen, A. (2001). Containment landfills: the myth of sustainability. Engineering Geology 60, 3.

[5] Augenstein, D., Morck, R., Reinhart, D., Yazdani, R., \& Pacey, J (n.d.). THE BIOREACTOR LANDFILL - AN INNOVATION IN SOLID WASTE MANAGEMENT. THE BIOREACTOR LANDFILL - AN INNOVATION IN SOLID WASTE MANAGEMENT, 1-9.

[6] Baldwin, T. D., Stinson, J., \& Ham, R. K. (1998). DECOMPOSITION OF SPECIFIC MATERIALS BURIED WITHIN SANITARY LANDFILLS . JOURNAL OF ENVIRONMENTAL ENGINEERING.

[7] Benson, C., Barlaz, M., Lane, D., \& Rawe, J. (2007). Practice review of five bioreactor/recirculation landfills. Waste Management 27, 13-28.

[8] Chiemchaisri, C., Chiemchaisri, W., Nonthapund, U., \& Sittichoktam, S. (2002). ACCELERATION OF SOLID WASTE BIODEGRADATION IN TROPICAL LANDFILL USING BIOREACTOR LANDFILL CONCEPT.

[9] chromacademy. (n.d.). Retrieved 2018, from chromacademy: https://www.chromacademy.com/

[10] Davis, M. L., \& Cornwell, D. A. (2008). Introduction to Environmental Engineering Fourth Edition. McGraw-Hill

[11] Dillah, D. D., Panesar, B., Gornto, M., \& Dieleman, B. L. (n.d.). New and Improved Implementation of the First Order Model for Landfill Gas Generation or Collection. Reston.

[12] El-Fadel, M., \& Khoury, R. (2000). Modeling Settlement in MSW Landfills: a Critical Review. Critical Reviews in Environmental Science and Technology.

[13] FAO. (1984). Better Farming Series 31. Biogas: What it is; How it is Made; How to Use it. FOOD AND AGRICULTURE ORGANIZATION OF THE UNITED NATIONS.

[14] FAO. (1986). Better Farming Series 32. Biogas 2: Building a Bette Biogas Unit. FAO Better Farming Series.

[15] Ghosh, S., \& Hasan, S. E. (2010). SANITARY LANDFILL. ENVIRONMENTAL AND ENGINEERING GEOLOGY - Vol. III Sanitary Landfill, 1-7. 
[16] Gupta, S., Choudhary, N., \& Alappat, B. J. (2007). Bioreactor Landfill for MSW Disposal in Delhi. Proceedings of the International Conference on Sustainable Solid Waste Management.

[17] HERBERT, L. (2007). CENTENARY HISTORY OF WASTE AND WASTE MANAGERS IN LONDON AND SOUTH EAST ENGLAND. In L. HERBERT, CENTENARY HISTORY OF WASTE AND WASTE MANAGERS IN LONDON AND SOUTH EAST ENGLAND (p. 11). The Chartered Institution of Wastes Management.

[18] Hosseini, S., Yaghmaeian, K., Yousefi, N., \& Mahvi, A. (2018). Estimation of landfill gas generation in a municipal solid waste disposal site by LandGEM mathematical model. Global J. Environ. Sci. Manage., 493-506.

[19] International Best Practices Guide for LFGE Projects. (2012). Global Methane Initiative.

[20] J.Wiszniowski, Robert, D., Surmacz-Gorska, J., Miksch, K., \& Weber, J. (2006). Landfill leachate treatment methods: A review. Environ Chem Lett, 1.

[21] KASZUBSKA, M., \& WZOREK, M. (2017). The Bioreactor - an Innovative Method of Disposal of Solid Waste. Economic and Environmental Studies Vol. 17, No. 2 (42/2017), 347-361, 2-14.

[22] Kumar, S., Gaikwad, S., Shekdar, A., Kshirsagar, P., \& Singh, R. (2004). Estimation method for national methane emission from solid waste landfills. Atmospheric Environment 38, 1-7.

[23] LONG, Y., LONG, Y.-Y., LIU, H.-C., \& SHEN, D.-S. (2009). Degradation of Refuse in Hybrid Bioreactor Landfill1. BIOMEDICAL AND ENVIRONMENTAL SCIENCES 22, 303-310.

[24] Manyi-Loh, C. E., Mamphweli, S. N., Meyer, E. L., Okoh, A. I., Makaka, G., \& Simon, a. M. (2013). Microbial Anaerobic Digestion (Bio-Digesters) as an Approach to the Decontamination of Animal Wastes in Pollution Control and the Generation of Renewable Energy. International Journal of Environmental Research and Public Health ISSN 1660-4601, 1.

[25] NAUE. Geotextiles for filtration and separation. HDPE type. (2010). Germany.

[26] Reddy, K. R., Hettiarachchi, H., Giri, R. K., \& Gangathulasi, J. (2015). Effects of Degradation on Geotechnical Properties of Municipal Solid
Waste from Orchard Hills Landfill, USA. Int. J. of Geosynth. and Ground Eng.

[27] Schroth, M., Eugster, W., Gómez, K., Gonzalez-Gil, G., Niklaus, P., \& Oester, P. (2011). Above- and below-ground methane fluxes and methanotrophic activity in a landfill-cover soil. Waste Management.

[28] Steinhause, E. S., \& Fourmont, S. (2015). Innovative Approach to Landfill Gas Collection and Control. Geosynthetics.

[29] T.Williams, P. (2005). Waste Treatment and Disposal second edition. Leeds: John Wiley \& Sons.

[30] The Bioreactor Landfill Next Generation Landfill Technology . (n.d.) WASTE MANAGEMENT Bioreactor Program.

[31] Tse, A. C., \& Adamu, C. I. (2012). ASSESSMENT OF ANTHROPOGENIC INFLUENCE ON QUALITY OF GROUNDWATER IN HAND-DUG WELLS IN PARTS OF MAKURDI METROPOLIS, NORTH CENTRAL NIGERIA. Ife Journal of Science vol. 14, no. 1, 1.

[32] U.S. Army Corps of Engineers. (2013). LANDFILL GAS COLLECTION AND TREATMENT SYSTEMS.

[33] U.S. Department of Agriculture, U.S. Environmental Protection Agency, U.S. Department of Energy. (2014). Biogas Opportunities Roadmap.

[34] USEPA. (2003). Evapotranspiration Landfill Cover Systems Fact Sheet. Solid Waste and Emergency Response (5102G), 1

[35] USEPA. (2005). GUIDANCE FOR EVALUATING LANDFILL GAS EMISSIONS FROM CLOSED OR ABANDONED FACILITIES Washington, DC: U.S. Environmental Protection Agency Office of Research and Development.

[36] USEPA. (2007). BIOREACTOR PERFORMANCE. USEPA.

[37] Warith, M. (2002). Bioreactor landfills: experimental and field results. Waste Management, 1-2.

[38] WTW. (2004). Retrieved 2018, from http://www.durko.com.tr/Uploads/Dokuman/4a7e9ffaf294a2fbd744d00 b40ed2638.pdf

[39] Yuen, S. (2001). Bioreactor landfills: Do they work? Geoenvironment 2001: 2nd ANZ Conference on Environmental Geotechnics. 